\title{
Diálogo ecumênico sobre Maria: Um estudo teológico sobre a contribuição do Grupo de Dombes em aproximação com a Lumen Gentium
}

Orientadora: Maria Teresa de Freitas Cardoso

Mestranda: Lêda Ventura Carneiro

Área de Concentração: Teologia Sistemático-Pastoral

Linha de Pesquisa: Fé e Cultura

Projeto de Pesquisa: Diálogo ecumênico e inter-religioso em seus movimentos e seus documentos

A presente dissertação trata da questão de Maria dentro do Cristianismo, no âmbito do diálogo entre a Igreja Católica e as Igrejas protestantes. Partimos de uma abordagem sobre o ecumenismo na atualidade, com ênfase no ecumenismo espiritual, para situarmos um contexto no qual se pode aprofundar o tema de Maria. A perspectiva que adotamos foi a aproximação do ensinamento do Magistério da Igreja, conforme o Capítulo VIII da Constituição Lumen Gentium, com o qual confrontamos o livro do Grupo de Dombes Maria no desígnio de Deus e a Comunhão dos Santos, que tomamos com ponto central desta dissertação. Esse livro foi vivamente investigado e apresentamos um resumo do seu conteúdo com suas propostas de interesse ecumênico. Do mesmo livro levantamos as ideias que são tratadas nas seções finais da explanação. Nestas seções, iniciamos por enfatizar aspectos do diálogo com a Comissão Internacional Anglicano-Católica Romana (ARCIC) e a Federação Luterana Mundial. A seguir, identificamos pontos de contato do livro de Dombes e da Constituição Lumen Gentium com a Exortação Marialis Cultus, como chave para aproximações sobre uma visão da figura de Maria, tendo também em conta a ótica de alguns outros autores, em contribuições atuais. Desenvolvemos, no final, alguns aspectos teológicos e pastorais do tema, ainda em perspectiva ecumênica, e apontamos, em especial, para os elementos promotores 
de consenso entre as Igrejas verificados na pesquisa. Foram priorizadas metodologias e propostas que pudessem servir de base para o desenvolvimento do diálogo ecumênico sobre Maria.

Palavras-chave: Diálogo ecumênico. Maria. Grupo de Dombes. Lumen Gentium. 